\title{
Mourning and Glory: Toward Affective Histories of Violence in Africa over la Longue Durée
}

\author{
Richard Reid
}

The study of emotions in African history is in its infancy, although it is expanding rapidly as a new frontier in scholarly work on the modern era. Considering the violent tumult experienced by the continent over the past two centuries, it seems apposite to begin to explore the role of emotions in the experience and interpretation of those processes of change, which are ongoing at the time of writing. This paper represents an attempt to contribute to the emerging historiography on emotions history in Africa. It is specifically concerned with the power of melancholy, mourning and memory in the context of war and other forms of violent conflict. The paper seeks to adopt a longue durée perspective, encompassing the nineteenth and twentieth centuries, though the bulk of the source material is located in the colonial and postcolonial periods and this is reflected in the weight of the analysis. The analysis itself is concerned with both individual and collective interpretations of the violent past, but the central focus is an assessment of how states and societies mourn the dead; and how they develop processes and systems of socio-political control and memory based on experiences of profound loss and bitter discontent, as well as of supposed military triumph.

Keywords: war, violence, militarism, memory, mourning, history

Working among the Nyoro people of Uganda in the 1950s, the anthropologist John Beattie encountered a markedly downcast, dispirited community, gripped by profound melancholy. Bunyoro, one of Uganda's most ancient kingdoms, was not in a happy state: the district had been regarded by colonial officials, Beattie wrote, as 'a dead end' for many years. ${ }^{1}$ The Nyoro were apathetic, lazy, prone to alcoholism, crippled by a deep-set sense of their own inferiority, and almost obsessively nostalgic for a glorious past long gone. They were also chronically infertile, with one of the lowest birth rates anywhere in Uganda.

1 John Beattie, The Nyoro State (Oxford: Clarendon Press, 1971), 31. I am grateful to the anonymous reviewers of an earlier version of this article for their constructive comments. 
'[M] any of them believed', wrote Beattie,

that the Europeans were actively concerned to maintain this state of affairs, so that eventually the Banyoro people would die out, and the Europeans could take over their country for themselves. These factors, allied with a profound nostalgia for their country's glorious past, combined to create an impression of Nyoro lack of confidence, self-disparagement, and mistrust ... ${ }^{2}$

Naturally enough, perhaps, Beattie soon discovered that they weren't quite as depressed as all that - greater intimacy with Nyoro friends and colleagues dissipated the initial impression somewhat - but he maintained that there was, nevertheless, something in it. $^{3}$ As the Katikiro, or prime minister, of Bunyoro told Beattie in 1953, 'Our spirit is dead'. ${ }^{4}$ Beattie's findings echoed those of a missionary half a century earlier. In 1905, Miss Chadwick, working in the Nyoro town of Hoima, found the experience somewhat miserable: 'To one accustomed to the gay friendliness of the Baganda the cold and indifferent, if not suspicious manner of their Banyoro sisters comes with something of a shock'. ${ }^{5}$ There were good reasons for the collective depression of the Nyoro. In the 1890s, the kingdom had been subjected to sustained attack by a British colonial army, operating in alliance with Bunyoro's neighbour and historic rival, the Buganda kingdom. Together, the British and the Ganda devastated Bunyoro, whose king, the redoubtable warrior Kabalega, had refused to come to terms with the invaders and who was seen as an outright savage by the British as a result. ${ }^{6}$ In the decades that followed, the Nyoro, marginalised and defeated, wallowed in nostalgia for a precolonial past of military greatness and regional hegemony $;^{7}$ suffering became part of their collective psyche, as did loss - not just of independence, but of a swathe of territory (known as the 'Lost Counties') to Buganda,

2 Beattie, Nyoro State, 32.

3 Ibid.; also Harold Ingrams, Uganda: A Crisis of Nationhood (London: HMSO, 1960), 238-9.

4 Quoted in Beattie, Nyoro State, 31.

5 Church Missionary Gleaner, XXXII (1905), 70.

6 For example, Sir Henry Colvile, The Land of the Nile Springs; being Chiefly an Account of how we Fought Kabarega (London: Edward Arnold, 1895).

7 Beattie, Nyoro State, 31-2; Ingrams, Uganda, 241-2; Shane Doyle, Crisis and Decline in Bunyoro: Population and Environment in Western Uganda, 1860-1955 (Oxford: James Curry, 2006), 165-6. 
which stood as both physical affront and grim representation of psychological state until the early 1960 s. $^{8}$

These are early days in the study of emotions history in Africa, though it is an emerging field. ${ }^{9}$ Work on literary culture, in particular, reveals both the extraordinary potential for, and the limits imposed on, the reconstruction of the affective, focused as it is on the discovery of what are broadly termed 'tin trunk' archives: personal papers, letters, diaries, memoirs, and a range of unpublished and published ephemera. ${ }^{10}$ Where these do not exist, emotional lives and cultures of affect are rather more difficult to discern, especially amidst the sound and fury of official archives, and particularly those written by foreigners. And so, as in other areas of African historical study, there are methodological constraints in the context of emotions history, and especially so over la longue durée. There are also conceptual challenges - not least in the sense that the larger field of emotions history is somewhat Eurocentric, ${ }^{11}$ especially noteworthy in studies of happiness, for example. ${ }^{12}$

To some extent I am interested in expressive behaviour, but above all this paper is concerned with instrumental behaviour, specifically the political and social mobilisation of affect. As Fierke has argued, '[e]motion is expressed in diverse ways and is often at the heart of identity construction, contestation and conflict'; ${ }^{13}$ and I draw inspiration from work that refutes the traditional

8 Colonial Office, Uganda: Report of a Commission of Privy Counsellors on a Dispute between Buganda and Bunyoro (London: HMSO, 1962).

9 Lynn M. Thomas and Jennifer Cole, eds, Love in Africa (Chicago: University of Chicago Press, 2009); 'Anxiety in and about Africa,' conference organised by the Centre for Research in the Arts, Social Sciences and Humanities, University of Cambridge, 15-16 June 2016, http://www.crassh.cam.ac.uk/events/26188; D. L. Schoenbrun, 'A Mask of Calm: Emotion and Founding the Kingdom of Bunyoro in the Sixteenth Century,' Comparative Studies in Society and History 55, no. 3 (2013): 634-64.

10 Karin Barber, ed., Africa's Hidden Histories: Everyday Literacy and Making the Self (Bloomington IN: Indiana University Press, 2006).

11 This is particularly true in more scientific research: see for example Jan Plamper, The History of Emotions: An Introduction, trans. Keith Tribe (Oxford: Oxford University Press, 2015). A more global reach is attempted in Susan J. Matt and Peter N. Stearns, eds, Doing Emotions History (Urbana IL: University of Illinois Press, 2014), which includes a chapter on China.

12 Darrin McMahon, The Pursuit of Happiness: A History from the Greeks to the Present (London: Penguin, 2006); William Davies, The Happiness Industry: How the Government and Big Business Sold Us Well-Being (London: Verso, 2015).

13 K. M. Fierke, 'Emotions in IR: The "Dog That Did Not Bark",' E-International 
idea that there is a clear separation between rationality and emotion, whether in terms of the role of affect in underpinning domestic political culture, or in global responses to poverty, or sudden catastrophe. ${ }^{14}$ Work on the American Revolution, notably, has demonstrated the potency of sentiment and affect in the moulding of the nation which emerged from those momentous events. ${ }^{15} \mathrm{~A}$ number of regimes in modern Africa have similarly relied heavily on emotion to bolster ostensibly 'rational' political arguments. ${ }^{16}$ The patchy historical record occasionally affords glimpses into the realm of private emotion in the context of violence - the expression of despair, or spiritual weariness, or something more akin to Freud's 'common unhappiness' ${ }^{17}$ - but our primary focus here is the manner in which emotion is carefully constructed with a view to political legitimacy and social cohesion, giving rise to forms of collective (or 'national') emotional states. Yet this does not mean they have no resonance among broader populaces: on the contrary, some such states have proven markedly robust precisely because of their resonance with, or at least co-option of, collective emotional identities.

Arguably the understanding and measurement of emotion over time is challenging in the African context owing to the question of cultural and historical specificity, and the idea that perhaps some forms of emotion are simply not expressed or are expressed in ways which the historical record fails to pick up. The racism and cultural prejudice in historical European descriptions of African society and psychological makeup render those texts highly problematic in writing emotions history during what was, ironically, one of the most turbulent and fascinating periods in modern African history - the era of political and military transformation, imperial conquest, and

Relations, 20 February 2015, http://www.e-ir.info/2015/02/20/emotions-in-ir-thedog-that-did-not-bark/.

14 Renee Jeffries, Reason and Emotion in International Ethics (Cambridge: Cambridge University Press, 2014).

15 Sarah Knott, Sensibility and the American Revolution (Chapel Hill: University of North Carolina Press, 2009); Andrew Burstein, Sentimental Democracy: The Evolution of America's Romantic Self-Image (New York: Hill and Wang, 1999).

16 The larger argument is made by Ken Booth and Nicholas Wheeler, The Security Dilemma: Fear, Cooperation and Trust in World Politics (Basingstoke: Palgrave, 2008); and Oded Lowenheim and Gadi Heimann, 'Revenge in International Politics,' Security Studies 17, no. 4 (2008): 685-724.

17 Sigmund Freud and Joseph Breuer, Studies in Hysteria (London: Penguin Books, [1895] 2004). 
colonial rule. Take, for example, Richard Burton's excoriating assessment of 'the East African's character' in the 1850s, in which the poor old native is simultaneously intellectually stunted and an emotional wreck - not exactly what we might term a reliable source. ${ }^{18}$

Nonetheless, there are very real possibilities as long as we remain flexible and vigilant in terms of both source and concept. Violent conflict and cultures of militarism provide a useful entry into emotional states and the politics of affect. The aim of this paper is to explore, tentatively, the ways in which we can examine cultures and practices of war and militarism in Africa through the prism of mourning, loss and defeat, as well as weary triumph and the abiding idea of lost glory. In so doing, I seek to meld emotions history with the burgeoning scholarship on historical memory and culture. Notably, for example, work by Jay Winter on the memorialisation of the First World War in Europe provides some useful pointers for our understanding of the relationship between war and memory; ${ }^{19}$ by the same token, national identities rooted in, and politically sanctioned cultures of, melancholy and mourning are the focus of Wolfgang Schivelbusch's powerful treatise on the consequences of defeat in which he uses the examples of the American South after 1865 , France after 1871 , and Germany after $1918 .{ }^{20}$ Affective responses to violence, or threat of it, infuse an excellent recent collection on nationalism and war, ${ }^{21}$ while the commemorations surrounding the centenary of the 1916 Easter Rising in Ireland occasioned some difficult revisions of long-accepted narratives, and prompted some highly emotional reinventions of those narratives. ${ }^{22}$

Given my focus on violence and post-violence, we must take note of some important critiques of the field of memory studies: that of Susannah Radstone, for example, who cautions against the universal applicability

18 Richard F. Burton, The Lake Regions of Central Africa (New York: Dover, [1860] 1995), 489-98.

19 Jay Winter, Sites of Memory, Sites of Mourning: the Great War in European Cultural History (Cambridge: Cambridge University Press, 1995).

20 Wolfgang Schivelbush, The Culture of Defeat: On National Trauma, Mourning, and Recovery, trans. Jefferson Chase (London: Granta, [2001] 2003).

21 John A. Hall and Sinisa Malesevic, eds, Nationalism and War (Cambridge: Cambridge University Press, 2013).

22 Richard S. Grayson and Fearghal McGarry, eds, Remembering 1916: The Easter Rising, the Somme, and the Politics of Memory in Ireland (Cambridge: Cambridge University Press, 2016). 
of 'trauma theory' (the idea that those who have experienced trauma are 'wounded' and in need of healing) and who emphasises the importance of understanding the cultures within which experiences happen and are remembered. ${ }^{23}$ Similarly, Wulf Kansteiner has questioned the tendency to remove from the analysis of memory complex local processes of production and consumption, and the peculiar social dynamics of collective memory. ${ }^{24}$ For that very reason, work on historical memory in the African context is increasingly important, for example in the context of slavery and the slave trade, and the drive to make sense of postcolonial nationhood. ${ }^{25}$ These are the frameworks, then, within which I have tried to position this paper. As will be clear, my primary field of research is eastern Africa; as appropriate and when the material permits, I have sought to draw comparisons from across the continent more broadly. Moreover, I have also tried to draw attention to some of the more enduring emotional responses to and interpretations of Africa in an imperial and global context.

\section{Triumph and disaster, melancholy and modernity}

Loss, yearning and melancholy attended military endeavour throughout Africa's deep past. In West Africa, the epic of Sunjata, the thirteenth-century founder of the Mali empire, is the emotional telling of a political narrative: of personal pain and early disadvantage (the child Sunjata was unable to walk), of exile and marginalisation and status as outcast, of the overcoming of seemingly insuperable obstacles, and ultimately of vengeance and retribution, as Sunjata returns to take his rightful inheritance, the throne of Mali. ${ }^{26}$ These

23 Susannah Radstone, 'Memory Studies: For and Against,' Memory Studies 1, no. 1 (2008): 31-9.

24 Wulf Kansteiner, 'Finding Meaning in Memory: a Methodological Critique of Collective Memory Studies,' History and Theory 41, no. 2 (2002): 179-97.

25 Mamadou Diawara, Bernard Lategan, and Jorn Rusen, eds, Historical Memory in Africa: Dealing with the Past, Reaching for the Future in an Intercultural Context (New York, Oxford: Berghahn, 2010); Brian Peterson, 'History, Memory and the Legacy of Samori in Southern Mali, c.1880-1898,'Journal of African History 49 (2008): 261-79; Rosalind Shaw, Memories of the Slave Trade: Ritual and the Historical Imagination in Sierra Leone (Chicago: University of Chicago Press, 2002); B. Jewsiewicki and V.Y. Mudimbe, 'Africans' Memories and Contemporary History of Africa,' History and Theory 32, no. 4 (1993): 1-11.

26 For example, Bamba Suso and Banna Kanute, Sunjata: Gambian Versions of the Mande Epic by Bamba Suso and Banna Kanute (London: Penguin, 1999). 
were stories of powerful affect, told by griots - the bards and historians of the region - who provide the emotional content essential to the full glory of the military epic. In the Great Lakes area of East Africa, mythical founders of states and societies in the early second millennium $\mathrm{CE}$ - usually the personification of several centuries' inward migration - were also emotional lodestars, bringing calm, or at least exhorting it, and becoming associated with political orders which might be necessarily violent in parts but which were ultimately designed to secure individual and collective wellbeing. Kintu, founding father of the Buganda kingdom and numerous others, exemplifies the process. ${ }^{27}$

Rulers who transgressed were deemed to have brought affective disharmony to the moral order - as the eighteenth-century king of Buganda in the story told to explorer Henry Morton Stanley discovered when he sought a meeting with the long-dead Kintu, the emotional barometer of the kingdom at particular moments in time. The latter, appearing briefly and spectrally in the depths of the forest, vanished abruptly when Kabaka (king) Mawanda committed an act of violence in front of him. ${ }^{28}$ One Nyoro chronicler in the 1930s tells the story of the mid-eighteenth century king Duhaga, who had rather a tendency to wage war incessantly: 'the land had little peace', according to 'K. W.', who was actually the reigning king of Bunyoro, writing under a pseudonym. 'His people ... advised him to hoist the flag of peace ... so as to have no more wars' ${ }^{29}$ No doubt this was, at least in part, the personalisation of a political mechanism curtailing the powers of the kingship; but it also reflected the dangers of emotional exhaustion for political stability. In Buganda and Bunyoro, war was certainly celebrated, and military endeavour considered an essential component of male, and indeed female, identity; ${ }^{30}$ but it needed

27 See for example Apolo Kagwa, The Kings of Buganda, trans. and ed. M. S. M. Kiwanuka (Nairobi: East African Publishing House, 1971), 1-9. For recent analysis, see David Schoenbrun, A Green Place, A Good Place:Agrarian Change, Gender, and Social Identity in the Great Lakes Region to the $15^{\text {th }}$ Century (Portsmouth NH: Heinemann, 1998); and N. Kodesh, Beyond the Royal Gaze: Clanship and Public Healing in Buganda (Charlottesville: University of Virginia Press, 2010).

28 H.M. Stanley, Through the Dark Continent, vol.1 (London: George Newnes, 1899), 276-81; also John Yoder,'The Quest for Kintu and the Search for Peace: Mythology and Morality in Nineteenth-Century Buganda,' History in Africa 15 (1988): 363-76.

29 'K. W.', 'The Kings of Bunyoro-Kitara, Part III', Uganda Journal 5, no. 2 (1937): $57-8$.

30 Richard J. Reid, 'War and Militarism in Precolonial Buganda,' Azania 34 (1999): 
to be righteous, and legitimate, which was only possible within an emotional framework which guaranteed reciprocity between governing and governed.

The story of Shaka, creator of the Zulu state in nineteenth-century southern Africa, recalls the moral and allegorical tones of Sunjata's epic at least in certain forms of the telling: here, again, is the outcast child (his mother conceives the boy out of wedlock), the need to overcome social stigma and marginality, the driving power of vengeful emotion, propelling Shaka to magnificent deeds and extraordinary brutality, depending on which versions of his biography one embraces. His was a potent tale of emotional violence: the frightening, enraged vision of African masculinity in contemporary sources, notably in the praise poetry which flourished from the early nineteenth century, ${ }^{31}$ or the product of emotional, and indeed physiological, trauma in the numerous highly stylised, even fanciful, accounts which proliferated later. 'Modern psychology', mused E. A. Ritter in 1955,

has enabled us to understand the importance ... of a child's unhappiness. Perhaps we may trace Shaka's subsequent lust for power to the fact that his little crinkled ears and the marked stumpiness of his genital organ were ever the source of persistent ridicule among Shaka's companions ...32

In later years, he was the deeply contested icon of African statecraft and warriorhood, or the emblem of a primordial African savagery, depending on which side you were on during Apartheid. ${ }^{33}$ But it was always a markedly emotive topic, as much about sentiment and feeling as any sense of empirical historicity. ${ }^{34}$

Meanwhile, the military revolution of which Shaka was a central part

45-60.

31 The collections produced by James Stuart in the 1920s are particularly noteworthy: for a fine summary, see Lupenga Mphande, 'Heroic and Praise Poetry in South Africa,' in The Cambridge History of African and Caribbean Literature, ed. F. Abiola Irele and Simon Gikandi, vol. 1 (Cambridge: Cambridge University Press, 2004), 71-97.

32 E. A. Ritter, Shaka Zulu: The Rise of the Zulu Empire (London: Longman, 1955), 13-14.

33 For example, see Dan Wylie, Myth of Iron: Shaka in History (Scottsville: University of KwaZulu-Natal Press, 2006); Carolyn Hamilton, Terrific Majesty: The Powers of Shaka Zulu and the Limits of Historical Invention (Cape Town and Johannesburg: David Philip Publishers, 1998).

34 Fierke, 'Emotions in IR,' np. 
pointed toward a more total militarism, and the practice of total war, with all its emotional repercussions. The same was true, too, of Emperor Tewodros of Ethiopia, whose own impassioned career contained some of the tropes noted above: a life begun in a certain marginality - the son of a minor nobleman, he was cheated out of his rightful inheritance and ultimately became a shifta, or bandit - and he slowly built military prowess on the harsh borderlands of northwest Ethiopia, abutting the Sudanese plains, in the course of the 1840s. ${ }^{35}$ Ultimately he was able to lay claim to the long-withered imperial throne - the Solomonic prize, king of kings of Ethiopia - propelled forward by anger and a sense of both personal and national grievance, and sustained by manifold military gifts. In contemporary depictions, he makes the transition from resolute, passionate saviour of the ancient Ethiopian state in the 1850s - as he appears in Plowden's early account ${ }^{36}$ - to fanatical, unhinged, tragedyin-the-making in the late $1860 \mathrm{~s} .{ }^{37}$ This is violent emotion, and emotional violence, gone beyond all sane limits, as attested to in local chronicles and writings, too: ${ }^{38}$ Tewodros had transgressed, and his raging political ambition - to rebuild Solomonic Ethiopia, expel Muslims and reclaim the ancient imperium's rightful territory, and to establish robust military and diplomatic alliances with Western powers, his natural Christian partners against Islam ended with his own suicide in $1868 .{ }^{39}$ His aggressive yet melancholic passion burned to the very end, when, enraged and impotent, he refused to fall into the hands of the British.

Shaka and Tewodros are particularly poignant examples, but glimpses into ideas about unhappiness and discontent in the nineteenth century, for example - an era of turbulence and trauma - are afforded by sources dealing

35 Among numerous contemporary accounts, see for example Henry Stern, Wanderings among the Falashas in Abyssinia (London: Frank Cass, [1862] 1968), 64-6. See also D. Crummey, 'The Violence of Tewodros,' in War and Society in Africa, ed. B. A. Ogot (London: 1972), 67ff.

36 Walter Chichele Plowden, Travels in Abyssinia and the Galla Country (London: Longmans, Green, 1868), 455-6.

37 H. Blanc, A Narrative of Captivity in Abyssinia (London: Frank Cass, [1868] 1970), 5.

38 Richard Pankhurst, ed., The Ethiopian Royal Chronicles (Addis Ababa: Oxford University Press, 1967), 151.

39 For example, Henry Morton Stanley, Coomassie and Magdala: The Story of Two British Campaigns in Africa (New York: Sampson Low, Marston, Low and Searle, 1874). 
with war and attendant suffering. In the 1860s, one of Emperor Tewodros's veteran military commanders, Gebre, was said to have 'hated war and signed for peace'. ${ }^{40}$ Likewise, in the area of modern-day Tanzania, the great Nyamwezi war leader Mirambo told a missionary in the early 1880s that he wished his enemies 'would let him live in peace; for he had been fighting ever since he was a little boy, and now the only fighting he wanted to do was ... with elephants in the forest'. ${ }^{41}$ War-weariness was not uncommon in a turbulent and violent nineteenth century: as an Ethiopian chief wrote to his European friend in 1860, '[t]hough my country is good, it is always at war. It is full of misery because there is always war amongst us. I would like to tell you about our misery ... ${ }^{42}$

The twentieth century witnessed the affective interpretation of this turbulent era and, as we have noted, the period of European conquest. Bunyoro encapsulates in stark terms the affective impact of the age of imperial conquest, but it is hardly unique. Across the continent in the late nineteenth and early twentieth centuries, states and societies responded in emotional terms to defeat and struggle, often incorporating affect - centred on melancholy and mourning - into cultural production and political discourse. The Sukuma of northern Tanzania composed songs in the early years of the twentieth century which conveyed the sadness of doomed warriorhood and the death of youth before the advance of European weaponry. ${ }^{43}$ Ethiopia would survive as a sovereign state beyond the European partition of the continent, but the memory of Tewodros's self-sacrifice was embedded in the minds of subsequent generations of Ethiopians. ${ }^{44}$ Rather less celebrated

40 Clements Markham, A History of the Abyssinian Expedition (London: Macmillan \& Co., 1869), 328.

41 Incoming, Box 4: Willoughby to Thompson, 27 November 1882, London Missionary Society Archives (SOAS), Central Africa.

42 Neguse Welde Mikael to E. A. Thouvenal, 12 March 1860, in Tewodros and his Contemporaries: Acta Aethiopica, ed. Sven Rubenson, vol. 2 (Addis Ababa and Lund: Addis Ababa University Press / Lund University Press, 1994).

43 H. Koritschroner, 'Some East African Native Songs,' Tanganyika Notes and Records 4 (1937): 56. The use of such sources is critical in the attempt to reconstruct otherwise concealed histories: see Susan J. Matt, 'Recovering the Invisible: Methods for the Historical Study of the Emotions,' in Doing Emotions History, ed. Matt and Stearns, 48-9.

44 Taye Assefa, 'Tewodros in Ethiopian Historical Fiction,' Journal of Ethiopian Studies 16 (1983): 115-28. 
is the case of Isike, ruler of Unyanyembe in Tanzania, who blew himself up while under siege by German troops in January $1893 .{ }^{45}$ These were acts of self-destruction driven by despair in the face of military defeat. Death of a more quotidian kind, though no less poignant, is described by Chinua Achebe in his classic novel Things Fall Apart: here, the protagonist, Okonkwo, hangs himself in a rather shocking finale because he has lost control of his life and his community on the eve of the British conquest of Nigeria. ${ }^{46}$ The age of imperial expansion, of global military contact, brought with it particular visions of the dead, a peculiar emotionality around military endeavour, triumph and disaster which was the product of the era of armed contact in Africa and elsewhere.

In Uganda in the early decades of the twentieth century, local writing reflected the often deeply emotional historicisation of the violent events of the late nineteenth century and the advent of the new colonial order. This was especially evident in Buganda, where histories were written with a view to reinforcing ideas about the role of kings as providing the affective foundations of state and society, and in particular placing emphasis on the degree to which the emotional character of the warrior was pivotal in grasping Buganda's historic success: the conceited and the unstable were laid low; the humble, the industrious, the loyal, were rewarded. ${ }^{47}$ To a very large extent this reflected authors' own early exposure to the Bible as historical source and standard reference: this was how history was to be written, namely infused with salutary stricture, morality and affect. Literacy, with its textual (and specifically scriptural) associations, also represented a new means of expressing emotion.

As that generation grew older, its members worried - in the universal way of ageing cohorts - that their achievements were being forgotten: creating a Christian kingdom, winning wars against the savagery of the past, and bringing the kingdom into enlightened modernity. They grew melancholic in their writings, and in the 1930s strove to remind readers of their seminal

45 Andrew D. Roberts, 'The Nyamwezi,' in Tanzania Before 1900, ed. A. D. Roberts (Nairobi: East African Publishing House, 1968), 142.

46 Chinua Achebe, Things Fall Apart (Oxford: Heinemann, [1958] 1986).

47 See especially the writings of Apolo Kagwa, Christian convert and dominant political figure in Buganda between the 1890s and the 1920s: Basekabaka be Buganda ('The Kings of Buganda'), 1901; Empisa za Buganda ('Customs of Buganda'), 1907; Ebika bya Buganda ('Clans of Buganda'), 1912. 
contribution. ${ }^{48}$ But in so doing some also romanticised the precolonial past - paradoxically in some ways, given that they were pioneers of Christian truth, premised on the idea of precolonial barbarity - and fretted about the extent to which the young had embraced everything that was wrong with modernity, and become neglectful of all that was progressive about it. ${ }^{49} \mathrm{At}$ least Ganda writers could rest in the knowledge that Buganda itself sat at the apex of the colonial order. Others used history-writing to lay claim to glorious martial pasts long gone. One prominent Nyoro writer sighed gloomily in the preface to his own work, first published in 1947: ' $t$ ] his book has been written for the sake of young people ... who lack the opportunity to study the history of Kitara [=Bunyoro] ... [P] eople nowadays are more interested in their jobs .... ${ }^{50}$ For the historians of Ankole district, there was something achingly poignant about the recollection of heroic deeds and the commitment to print of the praise-poems composed for long-dead warriors, as Uganda moved toward troubled decolonisation. ${ }^{51}$

But emotional transitions were evident in other contexts and cultural productions too. In the 1950s and 1960s, the Ugandan writer and scholar Okot p'Bitek - an Acholi from the north of Uganda, a territory that had been forcibly incorporated during the British conquest and subsequently positioned as a source of migrant labour feeding economic development in the south - produced work which reflected the Acholi struggle with the fallout of post-imperial violence, and ensuing neglect and decay. His novel Lak Tar ('White Teeth'), first published in the Luo language in 1953, is at times an unbearably sad book, describing the fate of a young man who cannot afford to get married owing to the spiralling costs of bridewealth, and who must

48 Lugolobi's Ekitabo Mbulire ('Let me tell') was written in 1933; Zimbe's Buganda ne Kabaka ('Buganda and Kabaka') in 1939; Miti's three-volume History of Buganda in around 1938; and Mukasa's three-volume Simuda Nyuma ('Don't turn back') between 1938 and 1942.

49 Kabaka Daudi Chwa, Education, Civilisation, and Foreignisation in Buganda (1935), reproduced in The Mind of Buganda: Documents in the Modern History of a Kingdom, ed. D. A. Low (London: Heinemann, 1971), 104-8.

50 John Nyakatura, Anatomy of an African Kingdom: A History of Bunyoro-Kitara, ed. G. N. Uzoigwe (New York: Anchor Books, 1973), ix.

51 Lazaro Kamugungunu and A. G. Katate, Abagabe b'Ankole (Kampala: Eagle Press, 1955); H. F. Morris, A History of Ankole (Kampala: Fountain, [1962] 2008); H. F. Morris, The Heroic Recitations of the Bahima of Ankole (Oxford: Oxford University Press, 1964). 
thus migrate south for work. ${ }^{52}$ This was a community devastated over the long term by colonial visions of modernity. A key character in the story, meanwhile, is the 'sergeant' in the protagonist's home village, a man who had served in the colonial army and who served as an emotive reminder of the few options open to young men in terms of paid work and social security. This particular strand of experience is dealt with in the Kenyan context by the Mau Mau fighter Waruhiu Itote, whose memoirs offer bitter reflections on his service in Burma during the Second World War. He encounters a British soldier who challenges him to explain why he, a Kenyan, is fighting to preserve the British Empire; and others provoke similar emotional turmoil in the young man's head. ${ }^{53}$ Itote returns from the war a nationalist, as he tells the reader, his conversion rooted in a troubled sensitivity which is itself the outcome of traumatic wartime experience. His own president, Jomo Kenyatta, might later exhort his fellow citizens to embrace the pain and sacrifice they had experienced on the path to nationhood without harbouring destructive feelings of grievance and anger; ${ }^{54}$ but emotional politics elsewhere demonstrated that it was not, alas, as simple as that.

\section{The power of loss: war, affect and the past in modern Africa}

The later twentieth century saw the emergence of governments and political movements rooted in particular forms of emotional response to violent postcolonial turmoil. National histories were often attended by gloomy prognoses, especially on the occasion of noteworthy anniversaries - of which there have been a large number of late, given that many African nations have recently turned fifty. These reflected both markedly melancholic summations of the recent past, particularly in countries in which violence had been seemingly endemic since independence, and disconsolate visions of the future, despite the best efforts of putatively forward-looking political elites. This was the case in the Democratic Republic of Congo, ${ }^{55}$ for example, and in Nigeria, where the government even sought to marginalise the past and

52 Okot p'Bitek, White Teeth (Nairobi: Heinemann, 1989).

53 Waruhiu Itote (General China), 'Mau Mau' General (Nairobi: East African Publishing House, 1967), 9-15.

54 Jomo Kenytta, Suffering Without Bitterness: the Founding of the Kenya Nation (Nairobi: East African Publishing House, 1968).

55 Thomas Fessy, 'DR Congo: Celebrating 50 years of chaos,' $B B C$ News, 30 June 2010, http://www.bbc.com/news/10449507. 
place emphasis on what was still to come. ${ }^{56}$ The past was pretty depressing, and in short did little for national morale.

In other cases, liberation fronts, steeped in armed struggle underpinned by an intensely emotional politics, heralded the rebirth of their respective national territories. From the 1960s onward, such movements emerged in South Africa, Mozambique, Angola, Zimbabwe, Ethiopia, Sudan, Rwanda, Uganda and Eritrea. In different but similar ways, they were the products of war, of course, but also of deep sadness, loss, and yearning. Their triumphs were not infrequently bitter ones, and on these affective politics did they seek to rebuild nations and reshape national memory. War was an emotional business, and in these societies the dead governed with an unchallengeable, if spectral, authority. Many of those armed liberation movements themselves were inspired by the emotive writings of Frantz Fanon, who had called, in effect, for the removal of emotional restraint in facing up to the true impact of colonial rule. It was hardly a coincidence that Fanon himself had been a psychiatrist, working among the traumatised victims of Algeria's war for independence in the 1950s. ${ }^{57}$

In Uganda, President Yoweri Museveni consistently proclaimed himself aghast at the nation's historical travails, and argued that the past - with its savage violence and tribal sectarianism - would hold Ugandans back until they embraced a new vision of the future ${ }^{58}$ To a very large extent, whether he realised it or not, Museveni was responding to deep-rooted regimes of feeling across Uganda itself - for example among the Nyoro, whose affective condition constituted a profound weakness in the body politic as a whole. As for that new vision for the future, unsurprisingly manifest in Museveni's own National Resistance Movement (NRM), it was underpinned by an ahistorical patriotism which recognised the bloody wars and illegitimate

56 Robin Denselow, 'Nigeria at 50: "Nothing to celebrate”,' $B B C$ Nerws, 24 September 2010, http://www.bbc.com/news/world-africa-11398020; 'President Jonathan's Centenary Address to the Nation,' Nigeria Bulletin, 27 February 2014, https://www. nigerianbulletin.com/threads/full-text-president-jonathans-centanary-address-tothe-nation.49340/.

57 Frantz Fanon, The Wretched of the Earth, trans. Constance Farrington (London: Penguin, [1967] 1990).

58 'Ours is a Fundamental Change,' swearing-in address, 29 January 1986, in Yoweri K. Museveni, What is Africa's Problem? (Minneapolis: University of Minnesota Press, 2000); 'For the Sins of Uganda I Repent - Museveni,' New Vision (Kampala), 18 October 2012. 
militarism of the Idi Amin and Milton Obote eras as tragic episodes from which Uganda must now 'move on'. History, to paraphrase Henry Ford, was all gloom; the future was now the only thing that could bring about the 'happiness' to which all political leaders ostensibly aspired, and that would require political unity and economic growth.

Something similar pertained to Ethiopia, whose ancient history was in one sense a tremendous asset in terms of national identity and claims to civilizational antiquity and continuity, but which in another sense produced profound anxiety - for here, too, was a history replete with violent conquests and deeply divisive iconography (Tewodros, hater of Muslims, exemplified the problem). As it neared its millennial celebrations (Ethiopian calendar) in 2007, the government sought to project a more sanitised vision of the past, and to avoid the overt celebration of those aspects of Ethiopian history liable to cause distress and anger in millions of citizens. Notably, and somewhat awkwardly, this included anything much to do with Amhara rule - which spanned some seven hundred years. ${ }^{59}$ In many respects, these were essentially misery narratives, which rendered highly emotive the struggle for cohesion and a sense of the past from which nations might 'move on' - while also legitimating the actions of seemingly immovable and increasingly unpopular incumbent regimes. In Ethiopia, a great deal of publicity was awarded to the Red Terror Martyrs' Museum in Addis Ababa, commemorating in an atmosphere of solemnity and mourning the deaths of thousands of people in the late 1970s at the hands of the then military government, known as the Derg. ${ }^{60}$ The Derg was also held responsible, directly or indirectly, for all manner of death through the 1980s - a murderous reign which was only brought to an end by the current government itself, the coalition known as the Ethiopian People's Revolutionary Democratic Front (EPRDF). Thus as with Museveni and the NRM in Uganda, who rooted their own legitimacy at least partially in the fertile soil of affect that was the horror of Idi Amin's reign in the 1970s, the EPRDF was able to use emotional political narrative and the public architecture of grief as mechanisms in the demonstration of its own essential benevolence. Nowhere was this more

59 Author's field notes and informal interviews, Addis Ababa, February 2014; Izabela Orlowska, 'Forging a Nation: the Ethiopian Millennium Celebration and the Multi-Ethnic State,' Nations and Nationalism 19, no. 2 (2013): 296-316.

60 Justin Ames, 'The Red Terror Martyr's Memorial,' The Velvet Rocket, 8 May 2010, https://thevelvetrocket.com/2010/05/08/the-red-terror-martyrs-memorial/. 
powerful - nor indeed more necessary, many might say - than in Rwanda, where the Rwanda Patriotic Front (RPF) by Paul Kagame has, since the mid-1990s, nurtured an emotional politics, and a markedly tight political grip, based on the awful tragedy of the genocide. ${ }^{61}$ The NRM, EPRDF and RPF each cultivated highly emotional historical narratives around war and loss which undergirded robust authoritarianism systems and appealed to both internal and external constituents.

The drive to explain such regimes in terms of fear is understandable, but insufficient, potent though that emotion is in the context of authoritarianism. ${ }^{62}$ These were political systems built on mourning as well as glory, rooted in a sense of affect which bound - or were supposed to bind - citizens to central truths about the very nature of life, its struggles, its sacrifices. Much of this is demonstrated, albeit in extremis, in the case of Eritrea under the Eritrean People's Liberation Front (EPLF). The latter waged a prolonged war against Ethiopia until 1991, when it captured the capital, Asmara, and became the de facto government of the devastated territory. Much of the focus in the years that followed was on the idea that the EPLF was a pragmatic and stoical movement, able to capitalise on the same qualities in a population that was impoverished but upbeat, determined, 'self-reliant'. But the very nature of the Eritrean struggle - the loss of life, the destruction and displacement, and the aftermath of 'liberation' - rendered the new state a profoundly emotional one.

In the public arena, two main events dominated the calendar. One was 24 May, Independence Day, which was characterised by much festivity and holiday merriment, but also public performances involving theatrical dancing which told the grim story of Eritrea's modern history - betrayal by the world, sinister enemies within, steadfast courage and sacrifice by Eritreans in pursuit of national destiny. The other was Martyrs' Day, 20 June, an altogether more solemn affair capped by a procession by candlelight by thousands of women through the capital, remembering the fallen heroes on whom the nation was built. ${ }^{63}$ Political culture was rooted in a kind of martyrology, in which the dead were regularly celebrated and commemorated, and new generations

61 See for example various papers in a special issue on 'Rwanda under the RPF: Assessing Twenty Years of Post-Conflict Governance,' Journal of Eastern African Studies 8, no. 2 (2014): 193-329.

62 For example, Corey Robin, Fear: the History of a Political Idea (Oxford: Oxford University Press, 2004).

63 Author's field notes and personal observations, between 1997 and 2008. 
were reminded in the starkest of terms of their predecessors' sacrifice. Songs, shows, literature all drove home the idea of loss and grief and wistful memory, and the need for further sacrifice. ${ }^{64}$ This became all the more acute in the late 1990s, when Eritrea returned to war with Ethiopia, and a new generation became caught up in loss of its own - its own dead, and its own loss of opportunities. Even - or, perhaps, especially - after a ceasefire was agreed in 2000, those affective politics became all the more entrenched.

The EPLF honed a culture of mourning which tied a younger generation to it, and from which an older generation could scarcely escape; it became all they knew. The real heroes, as some would whisper, were those who had been killed; ${ }^{65}$ and what was left was either flight from an increasingly authoritarian regime, or to become one of the living dead, those trapped in permanent national service, living in a state of 'no-war, no-peace' under a president, Isaias Afeworki, who was himself given to outbursts of extreme despair, anger, even apparent depression. ${ }^{66}$ And so, under the shadow of oppression, and haunted by histories of violence, from the early 2000s - especially following a major political clampdown in 2001 - the flight of the young from the country toward Europe began, driven by a more profound sense of loss and displacement even than that experienced by an earlier generation. ${ }^{67}$ As Eritreans trekked across Sinai at the hands of traffickers, and bobbed around on boats in the Mediterranean, they were in the grip of a deep mourning, their moment in the media spotlight framed by guilt and shame - both their own, and that of those watching the horror unfold. ${ }^{68}$ There could be little doubting the

64 An illustrative sample would include Alemseged Tesfai, Two Weeks in the Trenches: Reminiscences of Childhood and War in Eritrea (Lawrenceville NJ: Red Sea Press, 2002); Ghirmai Negash and Charles Cantalupo, eds, Who Needs a Story Contemporary Eritrean Poetry in Tigrinya, Tigre and Arabic (Asmara: Hidri Publishers, 2005); Jane Plastow, ed., Three Eritrean Plays (Asmara: Hidri Publishers, 2006). Again, for a useful theoretical frame, see Kansteiner, 'Finding Meaning'.

65 Author's field notes and informal interviews, Asmara, 2000 and 2001.

66 Dan Connell, Against All Odds: A Chronicle of the Eritrean Revolution (Lawrenceville NJ: Red Sea Press, 1997), 173; Michela Wrong, I Didn't Do It For You: How the World Betrayed a Small African Nation (London and New York: Fourth Estate, 2005), 375-6.

67 Zachary Laub, 'Authoritarianism in Eritrea and the Migrant Crisis,' Council on Foreign Relations, 16 September 2016, http://www.cfr.org/eritrea/authoritarianismeritrea-migrant-crisis/p37239.

68 'Italy Boat Sinking: Hundreds Feared Dead Off Lampedusa,' $B B C$ Nerws, October 3, 2013, http://www.bbc.com/news/world-europe-24380247. 
emotional and psychological stress this had placed on an entire generation disinterested in war stories but now unsure of its place in the world. ${ }^{69}$

Perhaps there was something of a generational shift here, in affective terms: a cohort, born in the 1980s and 1990s, which had different emotional needs and expectations, unwilling or unable to bear those of their parents. ${ }^{70}$ This compares with the generation gap in Britain between those who went through the 1930s and 1940s - whose fears and anxieties were explored with such skill and comprehension by Richard Overy - and the so-called 'babyboomers' who followed them in the 1960s and 1970s. ${ }^{71}$ In the European context, violence - and, specifically, its aftermath - has long been understood to have profound affective implications. It is little coincidence that Robert Burton's pioneering work on melancholy in the 1620s appeared against the backdrop of the Thirty Years War in continental Europe and so much violent turmoil even closer to home. ${ }^{72}$ Political systems, popular cultures, and national identities have been underpinned, indeed shaped, by memories of violence, loss and sacrifice. Such memories were also responsible, in peacetime, for heightened levels of anxiety and fear and general depression, ${ }^{73}$ while defeat itself might give rise to aggressive political identities, used to mobilise potent visions of the past. ${ }^{74}$ More broadly, emotional responses to violence have influenced the construction of History itself - as the cases of Eritrea and Uganda demonstrate very well. Isaias Afeworki and Yoweri Museveni used violent history to emotive effect, and their reading of Fanon had led, directly or indirectly, to regimes of authoritarian affect. Martyrdom and

69 The author has worked with dozens of Eritrean asylum seekers and their applications to remain in the UK.

70 Amanuel Mehreteab, Wake Up, Hanna! Reintegration and Reconstruction Challenges for Post-War Eritrea (Lawrenceville NJ: Red Sea Press, 2004); Dan Connell, Conversations with Eritrean Political Prisoners (Trenton NJ: Red Sea Press, 2005). For an account of overtly political disillusion, see Kidane Mengisteab and Okbazghi Yohannes, Anatomy of an African Tragedy: Political, Economic and Foreign Policy Crisis in Post-Independence Eritrea (Trenton NJ: Red Sea Press, 2005).

71 Richard Overy, The Morbid Age: Britain and the Crisis of Civilisation, 1919-1939 (London: Penguin, 2010).

72 Robert Burton, The Anatomy of Melancholy, ed. William Gass (New York: New York Review of Books, [1621] 2001); also John Harvey, The Story of Black (London: Reaktion Books, 2013), 140-43.

73 Overy, Morbid Age; Joanna Bourke, Fear: a Cultural History (London: Virago, 2005), 167-88.

74 Schivelbusch, Culture of Defeat; Winter, Sites of Memory. 
mortocracy were political systems built on grief, sorrow, mourning, giving rise to particular kinds of emotional states which in turn provided succour and legitimacy to the regimes themselves, and of course to particular historical narratives which underpinned them. Again this has been demonstrated by work done on the American Revolution. ${ }^{75}$ This was not a question of popular passivity, ${ }^{76}$ but a certain fatalism about the way the world worked which was broadly shared by governed and governing. Mourning was a potent means of narrating both triumph and disaster, and deployed as powerful means of socio-political control. Grief and government - most obviously in Eritrea, the grim mortocracy, mistrustful of the world - went together, underpinned by affective, and specifically melancholic, histories. ${ }^{77}$

\section{Empires of emotion}

There is no reason to doubt that missionaries and colonial officials - and anthropologists - found the Nyoro morose, melancholic, resigned; but the judgment of our Miss Chadwick in 1905 reminds us that European imperialism was itself of a distinctly emotional bent, and was rooted in a peculiarly affective view of the world, and of Europe's place in it. In 1733, the physician George Cheyne declared that the English should take pride in the fact that England was home to so many 'nervous diseases', as it was a palpable demonstration of the superiority of its civilisation. In other words, 'madness', wrote Elaine Showalter in her great work on women and madness in the nineteenth and twentieth centuries, 'was the by-product of English sensitivity, ambition, and intelligence ... [N]ervous afflictions were signs of progress and cultural superiority'. ${ }^{78}$ By implication, the more primitive races of the earth were incapable of such disorders, for they had not yet experienced the kind of progress which might thus play havoc with the emotions. In many respects, it was a view of the emotional life of the putative Savage which was echoed in Rousseau's treatise a few years after Cheyne, in which

75 Nicole Eustace, Passion is the Gale: Emotion, Power, and the Coming of the American Revolution (Chapel Hill: University of North Carolina Press, 2008); and also William M. Reddy, The Navigation of Feeling: A Framework for the History of Emotions (Cambridge: Cambridge University Press, 2001).

76 As was once suggested in 'Suddenly, dissent,' The Economist, 23 August 2001, http://www.economist.com/node/749280.

77 See Booth and Wheeler, The Security Dilemma.

78 Elaine Showalter, The Female Malady: Women, Madness and English Culture, 1830-1980 (London: Virago, 1987), 7. 
'infant man' was depicted as enjoying an existence of simple contentment, rudely and violently interrupted by the intrusions of modernity. ${ }^{79}$ Yet this interpretation was somewhat contradicted by the view, evident in the age of high imperialism between the late nineteenth and mid-twentieth centuries, of the 'primitive' as in fact highly emotional and prone to irrationality, especially in his practice of violence. Thus in 1880, for J. A. Farrer, while he incisively eschewed the normative dichotomy between 'savage' and 'civilised' warfare, the 'primitive races' were prone to throw themselves on the mercy of the supernatural, and endow gods with agency just as they abnegated their own. ${ }^{80}$ At the turn of the century, Charles Callwell, soldier and military theorist, pointed to the fragile morale of many 'savage' peoples, demonstrable in their vulnerable attachment to banners: capture these, Callwell suggested, and they often collapse in a dispirited heap. ${ }^{81}$ And of course in Turney-High's magnum opus on non-European war - produced in the 1940s but indicative of tropes developed in the latter half of the previous century - 'Primitive Man' at war was excessively emotional, driven by unstable and myopic passion, and gripped by fearful superstition. ${ }^{82}$

Still, the European practitioners of imperial violence were not themselves immune from emotional constraint. Consider two of Rudyard Kipling's poems, 'Recessional' (1897), composed for Queen Victoria's Diamond Jubilee, and 'The White Man's Burden'(1898), describing the US conquest of the Philippines. Both these poems were as depressive as they were celebratory, characterised by a glum sense of resignation about inevitable death and decline, by the melancholy which must invariably attend the youthful sacrifice for which Kipling sadly called. ${ }^{83}$ The global expansion of Britain was attended by a long, deep, melancholic sigh, which could be traced to the age of the Romantics who discovered a particularly emotive interpretation of English history but who also beheld the transience of worldly empires, witness Arnold's Dover

79 Jean-Jacques Rousseau, Discourse on the Origin of Inequality (New York: Dover, [1754] 2004), 24, 37.

80 J. A. Farrer, 'Savage and Civilised Warfare,' Journal of the Anthropological Institute of Great Britain and Ireland 9 (1880): $360 \mathrm{ff}$.

81 Col. C. E. Callwell, Small Wars: Their Principles and Practice (London: HMSO, 1906), 158.

82 H. H. Turney-High, Primitive War: Its Practice and Concepts (Columbia SC: University of South Carolina Press, 1949).

83 Both in Elleke Boehmer, ed., Empire Writing: An Anthology of Colonial Literature, 1870-1918 (Oxford: Oxford University Press, 1998), 272-4. 
Beach or Shelley's Ozymandias - and culminated in the nervous agitation manifest in Stoker's Dracula, Wells's War of the Worlds, or indeed Conrad's Heart of Darkness.

Nor was this confined to British imperial culture. When Fernando Martini, the governor of Eritrea at the time of Italy's defeat by Ethiopia at the battle of Adwa in 1896, was asked to make a contribution on Italy's African empire to the International Paris Exhibition of 1900, his response was chillingly timeless: he had nothing to offer, he said, save 'the bones of the dead, some military plans gone awry, and a list of sums of money thrown to the wind' ${ }^{84}$ One of the key justifications for late nineteenth-century European imperialism was precisely to bring happiness - though rarely named explicitly - to the lives of miserable and benighted Africans who knew only the most wretched of existences. ${ }^{85}$ By this time, there had been something of a decisive shift away from the Rousseauian notion of the beautiful, happy innocence of primitive man, and toward the idea of his barbaric despond. For that reason, too, colonial rule was supposed, in some shape for form, to facilitate African contentment, and therefore it was with alarm that by the 1930s it was increasingly clear that this goal had not been achieved. ${ }^{86}$

In an era, beginning in the eighteenth century, during which Europe's own sense of emotion (ideas about 'happiness', in particular) became more sharply defined and more prominent in political and cultural terms, ${ }^{87}$ 'Africa' was a markedly emotional proposition, and in many ways has remained so. This is reflected in the fixation with the continent's perceived benightedness and the developmentalism which underpins modern approaches to Africa, and in the highly (and consciously) affective responses to - and reportage of - a multitude of calamities, man-made and natural. ${ }^{88}$ For David Livingstone, the slave trade - and by extension, the condition of the continent more broadly

84 Quoted in Giuseppe Maria Finaldi, Italian National Identity in the Scramble for Africa: Italy's African Wars in the Era of Nation-building, 1870-1900 (Bern: Peter Lang, 2009), 13, 296.

85 This is the underpinning argument of F. D. Lugard, The Dual Mandate in British Tropical Africa (Edinburgh and London: William Blackwood, 1922).

86 For example,John Iliffe, A Modern History of Tanganyika (Cambridge: Cambridge University Press, 1979), 356-70.

87 Roy Porter, Enlightenment: Britain and the Creation of the Modern World (London: Penguin, 2000).

88 I explore this in more detail in 'Horror, Hubris and Humanity: the International Engagement with Africa, 1914-2014,' International Affairs 90, no. 1 (2014): 143-65. 
- was the 'open sore of the world'; ${ }^{89}$ more than a century later, British prime minister Tony Blair declared that poverty in Africa was 'a scar on the world's conscience'. ${ }^{90}$ Bob Geldof, ranting to camera, could exhort a global public, inured to images of suffering, to 'get its $\mathrm{f}^{* * *}$ ing money out' or call Ethiopian leader Mengistu Hailemariam a ' $c$ ***) to his face. ${ }^{91}$ Africa's various plights, and the violent conflict which attended them - famine and civil war in Ethiopia, or ethnic tension and genocide in Rwanda - produced relentlessly emotional responses in the Global North. ${ }^{92}$ The 'African experience' and Europe's interaction with the continent was framed in dramatically affective ways, whether through the rapture of salvation, ${ }^{93}$ or in terms of anxiety about perceived threat, ${ }^{94}$ or guilty melancholy about the putative 'state of Africa', a melancholy only punctuated by stereotyped images of Africans smiling and laughing through adversity. It is no coincidence that much of this intersected with modern ideas in the West about, and an increasing fixation on, happiness and wellbeing, and the 'entitlement' to both. Western perceptions about war 'elsewhere' have often been intensely emotional as a result, in an era defined - at least at the level of an international moral order - by a hegemonic belief in legitimacy in the deployment of arms, and attendant global judgments about savagery, barbarity, and illegitimacy in war.

89 Quoted in Roland Oliver, The Missionary Factor in East Africa (London: Longman, 1965), 34.

90 'Blair Promises to Stand by Africa', BBC News, 2 October 2001, http://news. bbc.co.uk/2/hi/africa/1575428.stm.

91 See for example 'The Day Music Changed the World?', Leeds Alumni Online (Autumn/Winter 2010) https://alumni.leeds.ac.uk/document.doc?id=219.

92 Jeffries, Reason and Emotion.

93 There is a long tradition of this - for example in the Ugandan context - from J. D. Mullins, The Wonderful Story of Uganda (London: Church Missionary Society, 1908) to Cedric Pulford, Eating Uganda:from Christianity to Conquest (London: Ituri, 1999).

94 Robert Kaplan, 'The Coming Anarchy,'Atlantic Monthly, February 1994, https:// www.theatlantic.com/magazine/archive/1994/02/the-coming-anarchy/304670/; Fierke, again, explores the potency of threat and perceived danger in 'Emotions in IR,' and in Critical Approaches to International Security (London: Polity, 2015). 


\section{Conclusions}

This paper has hopefully provided some insights, at least in a preliminary manner, into the ways in which ideas about violent conflict in Africa's past have been framed in emotional terms - both by Africans themselves and by foreign observers - as well as fundamentally influencing visions of history itself; and how emotional regimes have reinforced political authority, and received political wisdom, both in the deeper past and in more recent times. In sum, emotions and politics are indelibly intertwined, and regimes of affect lead to myriad political forms and political cultures, as well as serving as prisms through which history itself is refracted. Ideas about grief and memory are absolutely critical to understanding how politics and society function. We are confronted with evidence that political leadership and systems may encourage or discourage particular emotional states. Yet we must also take care to examine the connections between public and private feelings and expressions of discontent, as well as appreciating that in certain contexts these may well be distinct spheres. As John Corrigan has argued in the religious realm, there has been a growing tendency toward challenging the assumption that 'feeling' was something that happened in private, while the 'religious' was overtly public. ${ }^{95}$

It is obvious that intense emotion is both cause and effect of violent conflict. The self-immolation of Mohamed Bouazizi in Tunisia in December 2010 was a final act of despair, the culmination of years of frustration and suffering and stress, leading to one of the most remarkable popular uprisings of the modern age. ${ }^{96}$ The work of Okot p'Bitek in Uganda and Chinua Achebe in Nigeria offers us stories of loss and mourning, glimpses into quotidian discontent in the aftermath of violent upheaval; but in longue durée perspective they are portents, too, of conflict and trauma to come. Above all, this paper has explored the power of affective memory - particularly in the wake of violence - in shaping attitudes toward life and politics. The past continually changes in terms of emotional content and significance - and so, therefore, do ideas about progress. Ultimately, too, understanding key threads of emotions history - and emotional responses to political events, or emotional drivers of those events - can help us understand more clearly historical behaviours and

95 John Corrigan, 'Religion and Emotions,' in Doing Emotions History, ed. Matt and Stearns, 145.

96 Robert F. Worth, 'How a Single Match can Ignite a Revolution,' New York Times, 21 January 2011, http:/www.nytimes.com/2011/01/23/weekinreview/23worth.html. 
expectations, and may even enable us to undertake some forward planning, and more safely predict political eruption. Political and military leaders can exploit emotional states to a point - but at great peril do they go beyond it.

University of London R.J.Reid@soas.ac.uk 